Article

\title{
Toxicity Evaluation of Nanostructured Silica Orally Administered to Rats: Influence on Immune System Function
}

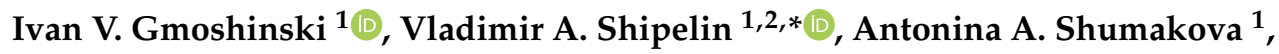 \\ Eleonora N. Trushina ${ }^{1}$, Oksana K. Mustafina ${ }^{1}$, Irina V. Safenkova ${ }^{3}$, Sergey A. Khotimchenko ${ }^{1,4}$, \\ Dmitry B. Nikityuk ${ }^{1,4}$ and Viktor A. Tutelyan ${ }^{1,4}$ \\ 1 Federal Research Centre of Nutrition and Biotechnology, 109240 Moscow, Russia; gmosh@ion.ru (I.V.G.); \\ antonina_sh@list.ru (A.A.S.); trushina@ion.ru (E.N.T.); mustafina@ion.ru (O.K.M.); \\ hotimchenko@ion.ru (S.A.K.); dimitrynik@mail.ru (D.B.N.); tutelyan@ion.ru (V.A.T.) \\ 2 Plekhanov Russian University of Economics, 115093 Moscow, Russia \\ 3 Research Centre of Biotechnology of the Russian Academy of Sciences, A.N. Bach Institute of Biochemistry, \\ 119071 Moscow, Russia; saf-iri@yandex.ru \\ 4 I.M. Sechenov First Moscow State Medical University (Sechenov University), 119991 Moscow, Russia \\ * Correspondence: v.shipelin@yandex.ru; Tel.: +7-495-698-5371
}

Received: 18 August 2020; Accepted: 15 October 2020; Published: 26 October 2020

\begin{abstract}
The experimental data on the oral toxicity of nanostructured amorphous silica $\left(\mathrm{SiO}_{2}\right)$, widely used in food supplements, pharmaceuticals, and cosmetics, in terms of its in vivo effect on the immune system, are contradictory. Therefore, this study aimed to assess the rat's immune function after $\mathrm{SiO}_{2}$ oral administration. In the first experiment, $\mathrm{SiO}_{2}$ was daily orally administered to Wistar rats for 92 days in doses of $0.1,1.0,10$, and $100 \mathrm{mg} / \mathrm{kg}$ of body weight (bw). In the second 28-day experiment, $\mathrm{SiO}_{2}$ in a dose of $100 \mathrm{mg} / \mathrm{kg}$ bw was daily orally administered to rats parenterally immunized with the food allergen ovalbumin (OVA) for the reproduction of systemic anaphylaxis reaction. Together with integral indices, we assessed intestinal permeability to protein macromolecules; hematology; CD45RA+, CD3+, CD4+, CD8+, and CD161a+ cells; cytokines TNF- $\alpha$, IL-6, and IL-10; and IgG to OVA. The results obtained showed that $\mathrm{SiO}_{2}$ has no effect on the severity of the anaphylactic reaction, but is capable inducing a toxic effect on the T-cell immune systems of rats. Estimated no observed adverse effect level NOAEL for $\mathrm{SiO}_{2}$ ranges up to $100 \mathrm{mg} / \mathrm{kg}$ bw in terms of its daily consumption for 1-3 months. Using $\mathrm{SiO}_{2}$ as a food additive should be the subject of regulation.
\end{abstract}

Keywords: silica; nanoparticles; rats; subacute toxicity; leucocytes; cellular immunity; cytokines; antibodies; systemic anaphylaxis; NOAEL

\section{Introduction}

Amorphous silicon dioxide (silica, $\mathrm{SiO}_{2}$ ) is widely used nowadays as a food additive (E551), and also as parts of a large number of tableted pharmaceuticals, many types of cosmetic products, and synthetic and natural flavors. The role played by silicon dioxide added to the listed kinds of products is reduced to its function as an anti-caking agent and carrier. In the present specification Joint FAO/WHO Expert Committee on Food Additives (JECFA) for $\mathrm{SiO}_{2}$ as a food additive [1], there is no information about the size of its particles, which allows the use of superfine amorphous $\mathrm{SiO}_{2}$, obtained by gas-phase hydrolysis of tetrachlorosilane of high purity. This material, also known as "Aerosil ${ }^{\circledR} "$, has the size of the primary nanoparticles (NPs) forming in the reactor of within 6-30 nm. These NPs subsequently form loose aggregates of the submicron size which are prone to dissociation under the influence of mechanical impact. Consequently, this form of $\mathrm{SiO}_{2}$ can be considered as 
consisting basically of NPs, so this is a nanomaterial (NM). Contents of $\mathrm{SiO}_{2}$ with particle sizes on the nanoscale in the food, cosmetic, and pharmaceutical products are not currently controlled, wherein the data about the possible toxicity of silica nanoparticles (NPs) with different sizes, porosity, and surface chemistry are contradictive. Toxicity of nanostructured amorphous $\mathrm{SiO}_{2}$ at the inhalation route of intake can be significant [2,3], whereas results that have been obtained with its oral route of intake do not coincide with each other. Hence, in particular, even a single administration to rats of monodisperse $\mathrm{SiO}_{2}$ NPs results in a series of both local and systemic toxic effects which are evident at a dose of less than $1000 \mathrm{mg} / \mathrm{kg}$ of body weight (bw) [4,5]. However, in the study [6] only marginal toxic effects of $\mathrm{SiO}_{2}$ nanoparticles manifested at a dose of $2500 \mathrm{mg} / \mathrm{kg}$ bw or more with repeated intragastric administration, and another study [7] did not reveal any adverse effects for both nanoparticles and microparticles of amorphous silica.

There is evidence of the ability of silica NPs to exert endothelial inflammation with hemostatic and thrombosis effects [8], and influence the state of the immune system [9,10], in particular, the severity of allergic reactions in the inhalation and intranasal route of entry [11].

The present paper aims to evaluate the influence of orally administered nanostructured $\mathrm{SiO}_{2}$ used as a food additive in pharmacy and cosmetics on the immune function of rats in order to establish, on the basis of these data, a dose of this NM not causing adverse effect (NOAEL-no observed adverse effect level).

\section{Materials and Methods}

\subsection{Characterization of Nanomaterial}

Studied ultrafine amorphous $\mathrm{SiO}_{2}$ was purchased in company "Silica" LTD (Russia, Moscow district, Dolgoprudny town) under the trademark "Orysil 300". Index "300" in the nomination of the product means specific surface in $\mathrm{m}^{2} / \mathrm{g}$ measured by the method of adsorption isotherms of inert gases. The product is an X-ray amorphous light white powder, giving upon sonication, opalescent colorless dispersion (colloidal solution) in water stable for at least two days. According to the manufacturer's data, $\mathrm{SiO}_{2}$ particles in the product were not porous. Silica particles were no coated with any organic materials.

Estimation of the size and shape of the particles in the product was made by atomic force microscopy (AFM), transmission electron microscopy (TEM), spectroacoustic method, and dynamic laser light scattering (DLS).

When studied by AFM, the $\mathrm{SiO}_{2}$ powder in an amount of $10 \mathrm{mg}$ was suspended in $5 \mathrm{~mL}$ deionized $\mathrm{H}_{2} \mathrm{O}$ and sonicated (duration $5 \mathrm{~min}$, frequency $44 \mathrm{kHz}$, power $\left.1 \mathrm{~W} / \mathrm{cm}^{3}\right)$. The suspension $(5 \mu \mathrm{L})$ was placed on the surface of freshly cleaved mica by dipping and incubated for $10 \mathrm{~min}$ at room temperature. Then, the excess liquid was removed by filter paper and dried. The AFM was performed using a Smart SPM-1000 atomic force microscope (AIST-NT, Moscow region, Russia) in a tapping mode. For high resolution, we used fpN01HAR cantilevers (Nanotuning, Moscow region, Russia) totally characterized and calibrated by the manufacturer and having a tip radius curvature of about $1 \mathrm{~nm}$. We prepared three identical specimens and measured two times for each sample. The samples were sequentially scanned in areas with the following dimensions: $35 \times 35 \mu \mathrm{m}^{2}, 20 \times 20 \mu \mathrm{m}^{2}, 5 \times 5 \mu \mathrm{m}^{2}$, and $1 \times 1 \mu \mathrm{m}^{2}$. The obtained images were analyzed using the Gwiddion software v.2.42 (Czech Metrology Institute, Czech Republic).

TEM study of the sizes and shapes of the particles of $\mathrm{SiO}_{2}$ preparation was done by transmission electron microscope JEM-100SKH (JEOL, Japan) at an accelerating voltage of $80 \mathrm{kV}$. Before the study, a suspension of $\mathrm{SiO}_{2}$ with a concentration of $1 \mu \mathrm{g} / \mathrm{cm}^{3}$ in water was processed in the same way as indicated in the case of AFM, sedimented on carbon-coated copper grids, and dried.

Spectroacoustic study of $\mathrm{SiO}_{2}$ dispersion was performed using a DT-1202 analyzer (Dispersion Technology Inc., Bedford Hills, NY, USA) in accordance with the method [12].

DLS study of $\mathrm{SiO}_{2}$ particles' distribution by size (hydrodynamic diameter) was made in particle analyzer Nanotrack Wave (Microtrac Inc., York, PA, USA). The data were analyzed with the assumption 
of the presence of spherical opaque particles using software FLEX 11.0.0.1 (Microtrac Inc., York, PA, USA). In the cases of spectroacoustic and DLS studies, the suspension of $\mathrm{SiO}_{2}$ in deionized water was sonicated immediately before the study with duration $5 \mathrm{~min}$, frequency $44 \mathrm{kHz}$, and power $1 \mathrm{~W} / \mathrm{cm}^{3}$ on a submersible ultrasonic processor.

\subsection{Animals and Ethics}

We used 170 male Wistar rats, which were purchased in Stolbovaya breeding nursery (Scientific Center for Biomedical Technologies, FMBA, urban-type settlement Stolbovaya, the Moscow region, Russia). The experiment was performed following the Order of the Ministry of Health of the Russian Federation number 199n dated 1 April 2016 “On approval of the rules of good laboratory practice". The design of the experiment was approved by the Ethics Committee of Federal Research Centre of Nutrition and Biotechnology (protocol number 2 of 9 September 2013). The rats were housed in groups of 3 animals in the polycarbonate cages under 12/12 h illumination conditions and a temperature of $22 \pm 1^{\circ} \mathrm{C}$; diet and water were provided ad libitum.

\subsection{Subacute 92-Day Experiment}

In the first experiment (Figure 1), five groups of animals were formed with 15 rats of the same age (about 7 weeks) in each with an initial average bw of $80 \mathrm{~g}$. During the study, all animals received a balanced semisynthetic diet identical in chemical composition to AIN93 [13]. Animals of group 1 (control) received deionized water which was used as a carrier for NM. Rats in the groups from 2 to 5 received nanostructured $\mathrm{SiO}_{2}$ in the form of a suspension in deionized water in the doses 0.1, 1.0, 10, and $100 \mathrm{mg} / \mathrm{kg}$ bw based on dry silica, respectively. Before the introduction to animals, the suspension was sonicated as described in Section 2.1. During the first 30 days of the experiment, the NM was administered by gavage, and during the subsequent 62 days, $\mathrm{SiO}_{2}$ suspension was added to animal feed; the $\mathrm{SiO}_{2}$ doses were calculated based on the consumption of the diet. Throughout the experiment, the rats were weighed daily on an electronic balance with an accuracy of \pm 1 g; morbidity, mortality, appearance, activity, behavior features, and state of the coat were observed.

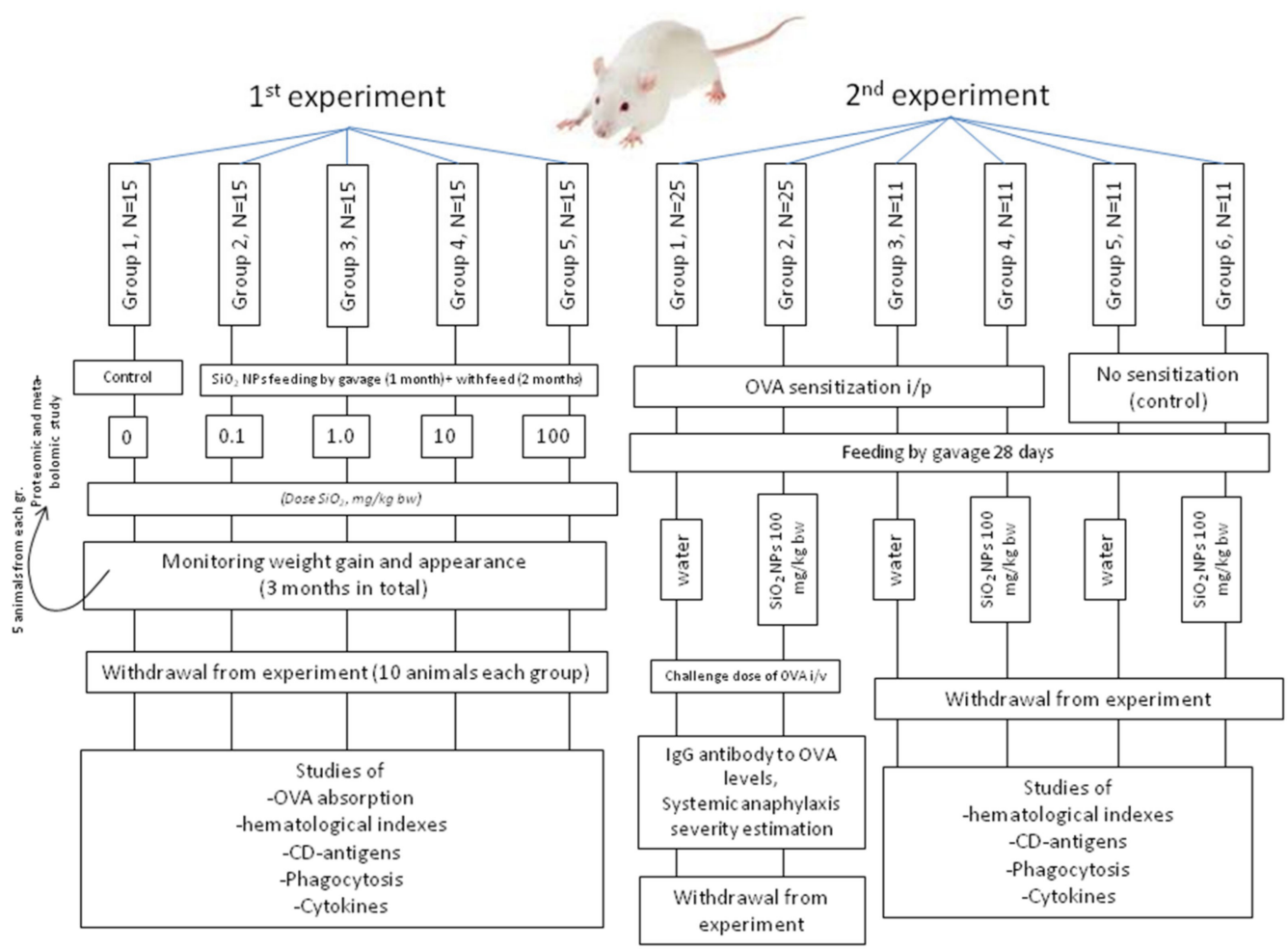

Figure 1. The scheme of the 1st and the 2nd experiments' designs. 
Animals were euthanized on day 93 by exsanguination from the inferior vena cava under ether anesthesia. Three hours before the end of the experiment, 8 or 9 rats from each group received by gavage chicken egg ovalbumin (OVA) dissolved in $0.15 \mathrm{M} \mathrm{NaCl}$ at a dose of $3 \mathrm{~g} / \mathrm{kg}$ bw per protein. The weights of the internal organs (liver, kidney, spleen, heart, testis, thymus, lung, adrenal gland) were determined by weighing on an electronic balance with an accuracy of $\pm 0.01 \mathrm{~g}$. Blood was collected in anticoagulant $(0.01 \%$ by weight of tripotassium ethylene diamine tetraacetate EDTA) and in a dry sterile tube for serum separation.

The intestinal barrier permeability for OVA macromolecules was evaluated by its concentration in the serum, determined by solid phase "sandwich" enzyme-linked immunoassay (ELISA), according to [14], with minor modifications. The magnitude of absorbed OVA amounts in percent of the administered dose was calculated in the whole blood flow based on mean blood mass in the amount of $6 \%$ of body weight according to reference data [15] and hematocrit of $44 \%$.

\subsection{Twenty-Eight-Day Systemic Anaphylaxis Model Experiment}

In the second experiment (Figure 1), 95 male Wistar rats with an initial average body weight of $160 \mathrm{~g}$ were divided into six groups of 25 (group 1), 25 (group 2), and 11 (groups 3-6) animals. During the experiment, the animals of all groups received a standard diet prepared in the vivarium of the Federal Research Centre of Nutrition and Biotechnology based on natural foods, balanced on macro- and micronutrients. Rats of $1 \mathrm{st}, 3 \mathrm{rd}$, and 5 th groups received by gavage deionized water in the amount of $10 \mathrm{~mL} / \mathrm{kg}$ bw. Rats of 2nd, 4th, and 6th groups daily received by gavage $\mathrm{SiO}_{2} \mathrm{NPs}$ at a dose of $100 \mathrm{mg} / \mathrm{kg}$ bw as a sonicated aqueous dispersion containing $1 \%$ of $\mathrm{SiO}_{2} \mathrm{NPs}$ by weight. On the 1 st, $3 \mathrm{rd}$, and 5 th day of the experiment, rats from 1-4 groups were immunized intraperitoneally by a dose of $100 \mu \mathrm{g}$ of 5-fold recrystallized OVA adsorbed on $10 \mathrm{mg}$ of freshly precipitated aluminum hydroxide as described in [16]. On day 21, the rats of these groups were injected with an additional $10 \mu \mathrm{g}$ of OVA under the same conditions to induce a secondary immune response. On the 29 th day, $0.5 \mathrm{~mL}$ of blood was taken from each of the tail veins of rats from groups 1 and 2 for the antibody determination; then $6 \mathrm{mg} / \mathrm{kg}$ bw OVA in sterile pyrogen-free $0.15 \mathrm{M} \mathrm{NaCl}$ was injected intravenously as a challenge dose for induction of systemic anaphylaxis. The protein solution was pre-filtered through a membrane filter with pores of $0.22 \mu \mathrm{m}$. Development the symptoms of an active anaphylactic reaction (AAR) was observed within $24 \mathrm{~h}$ after administration of the challenge dose; the severity of the reaction was evaluated in accordance with the scale of " 0 " being no reaction; " + "—chills, shortness of breath, itching; " ++ " —weakness, ataxia, cyanosis of the extremities; " +++ " - convulsions, paralysis; " ++++ " - death. Surviving animals of groups 1 and 2 were taken out of the experiment by a lethal dose of $\mathrm{CO}_{2}$ inhalation. Rats of the 5th and 6th groups were not immunized and served as controls to groups number 3 and 4 respectively.

Rats in groups 3-6 were taken out of the experiment by exsanguination from the inferior vena cava under deep ether anesthesia. Blood was collected in anticoagulant $(0.01 \%$ by weight of tripotassium EDTA) for determination of hematological and immune indices, and in a sterile dry test tube for the determination of serum cytokines.

\subsection{Hematological and Immunological Parameters}

Hematological indices were studied on hematology analyzer "Coulter AC TTM 5 diff OV" (company "Beckman Coulter", Indianapolis, IN, USA) with a standard set of reagents (manufactured by "Beckman Coulter", Villepinte, France). The defined parameters included the number of erythrocytes, leukocytes, hemoglobin concentration, hematocrit, mean cellular volume, mean corpuscular hemoglobin content, mean cellular hemoglobin concentration, platelet count, mean platelet volume, the relative number of platelets in the whole blood, and white blood cells (WBC) population composition.

Expression of antigens CD45RA, CD3, CD4, CD8, and CD161a on peripheral blood lymphocytes was determined by direct immunofluorescence staining of whole blood with a panel of monoclonal antibodies conjugated with fluorescent dyes, and lysing/fixing reagent kit (manufactured by "Beckman Coulter", Indianapolis, IN, USA). Lysis/fixation and staining of cells were performed according to the 
manufacturer's instructions. Analysis of the stained cells was performed on a flow cytometer "FC-500", manufactured by "Beckman Coulter", Indianapolis, IN, (USA) using the software "Cytomics CXP Software" (manufactured by "Beckman Coulter", Fullerton, CA, USA). Lymphocyte populations were isolated by gating on parameters small angle (FS) and side (SS) of light scattering. Next was the gating of CD3+ lymphocyte populations via fluorescence channels FL1 and SS Lin. Results were recorded on a two-parameter histogram distribution of CD3+ (from gate B) using monoclonal antibodies against CD4 and CD8, detected in fluorescence channel FL5 and FL4, respectively. Similarly, in a separate test the expressions of CD45RA and CD161a were determined. The total contents of CD45RA+ (B-lymphocytes), CD3+ (T-lymphocytes), and CD161a+ (natural killer) were expressed in percentages of the total number of lymphocytes analyzed (at least 104 events per animal). The contents of CD3+CD4+ (T-helper cells) and CD3+CD8+ (cytotoxic T) were determined as percentages of their share in the total number of CD3+ cells. The dimensionless immunoregulatory index (IRI) was calculated, which was the ratio of CD4+/CD8+ cells.

Study of the phagocytic activity of polymorphonuclear leukocytes in peripheral blood was performed by a standard method using a reagent kit Phagocytosis Assay Kit (IgG FITC), manufactured by "Cayman Chemical Company", Ann Arbor, MI, (USA) according to the instructions attached. The object of phagocytosis was latex particles opsonized IgG FITC. The cell suspension was incubated with the addition of latex to the whole animal blood for $30 \mathrm{~min}$ in two test tubes. Samples are analyzed on a flow cytometer using the program Cytomics CXP Software. Populations of neutrophils were isolated by gating on parameter FS, and SS of light scattering was evaluated by the number of cells via phagocytosed value fluorescence FITC. The analysis was performed twice: in the presence and absence of a phagocytosis stimulator-phorbol-12-myristate-13-acetate (PMA), whereupon a stimulation index was calculated for each blood sample studied.

Determination of cytokines IL-6, IL-10, and TNF- $\alpha$ in the serum of rats was performed by ELISA using commercial kits "Bioscience", produced by "Bender Med-Systems $\mathrm{GmbH}^{\prime}$ (Wien, Austria), following the manufacturer's recommendations. The intensity of humoral immune response to OVA in rats in groups 1 and 2 (second experiment) was evaluated by circulating specific IgG antibodies level using indirect ELISA on polystyrene. Antibody response was analyzed in terms of the level of antibodies in serum $\left(\mathrm{mg} / \mathrm{cm}^{3}\right)$, the level of the decimal logarithm, and the absorbance value in ELISA. Optical density was measured on an automatic immunoassay plate photometer "EFOS 9605" (Moscow, Russia).

\subsection{Statistics}

Statistical analysis was performed using SPSS 20.0 package (SPSS Inc., Chicago, IL, USA) according to the paired Student's $t$-test, nonparametric Mann-Whitney $U$-test, $\chi$-square criterion, criterion $U$ Fisher's angular transformation, and ANOVA. Differences were considered significant at a level of $p<0.05$.

\section{Results}

\section{1. $\mathrm{SiO}_{2}$ Characterization}

A TEM study of $\mathrm{SiO}_{2}$ suspension with a concentration of $1 \mu \mathrm{g} / \mathrm{cm}^{3}$ showed that particles on the grid were distributed mainly in the form of large loose aggregates consisting of primary particles with diameters less than $100 \mathrm{~nm}$. AFM showed the presence of NPs, which were mainly in the aggregated state. NPs aggregates were present in all scans with a scanned area of $20 \times 20 \mu \mathrm{m}^{2}$; the sizes of aggregates varied, reaching a maximum value of up to $2 \mu \mathrm{m}$ (in one of the measurements). It was found that the structural element for all aggregates was a particle with dimensions less than $100 \mathrm{~nm}$. The population of NPs in the composition of aggregates consisted of particles of rounded or nearly spherical morphology with a diameter ranging from 20 to $60 \mathrm{~nm}$. The representative TEM and AFM images of the studied samples of $\mathrm{SiO}_{2}$ are presented in Figure 2a,b. 


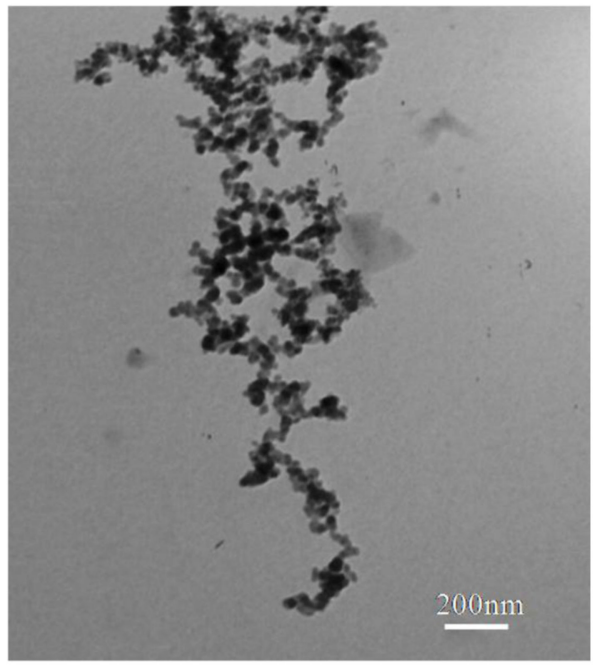

(a)

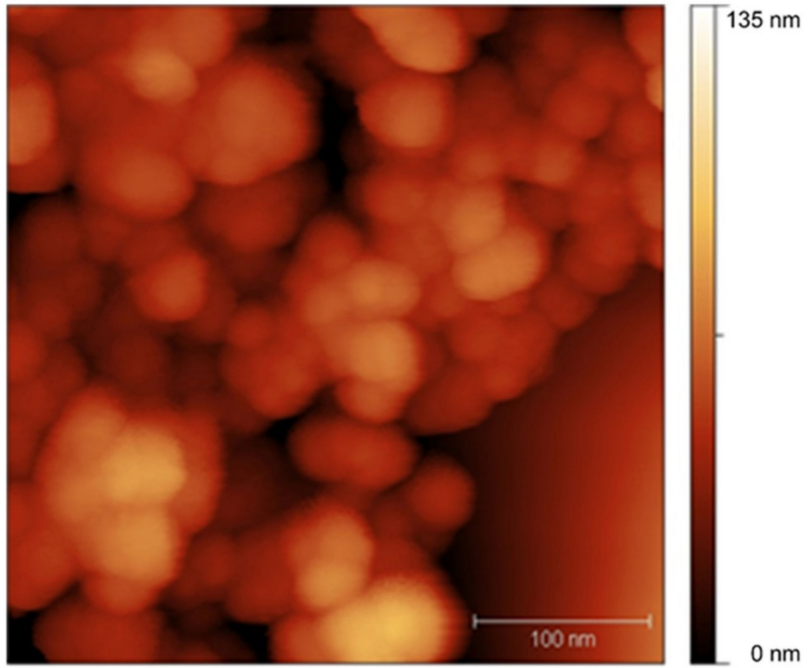

(b)

Figure 2. Representative images of $\mathrm{SiO}_{2}$ particles obtained by transmission electron microscopy (a) and atomic force microscopy $(\mathbf{b})$.

A spectroacoustic study of an aqueous suspension of $\mathrm{SiO}_{2}$ with a concentration of $5 \%$ by weight, treated or untreated with ultrasound, revealed a bimodal particle size distribution with a predominance of NPs with an average size of $20-40 \mathrm{~nm}$. Particle size analysis of the sample at a concentration of $1 \%$ by weight using dynamic light scattering showed that for the predominant fraction of NPs in the preparation: number average hydrodynamic diameter was $56.6 \pm 32.1 \mathrm{~nm}$; 90 th size percentile $-91.7 \mathrm{~nm}$ (Figure 3). The content of particle fraction with a diameter greater than $100 \mathrm{~nm}$ after sonication did not exceed $10 \%$ of the total number of particles.

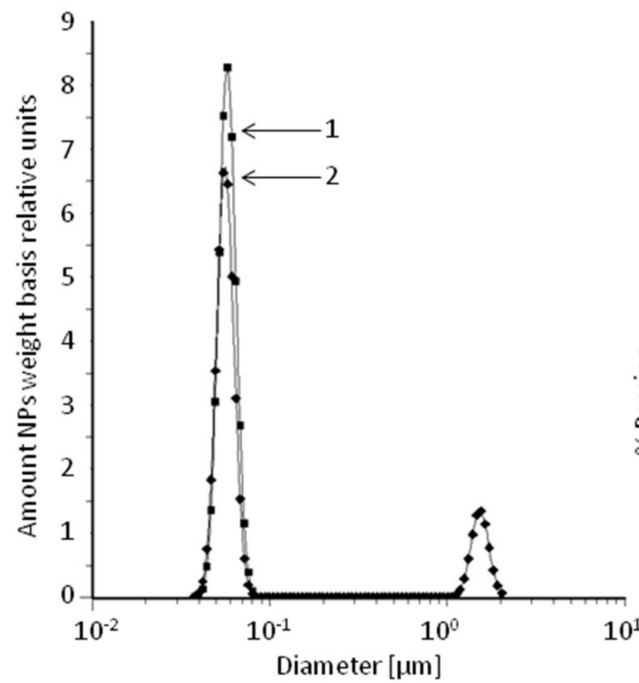

(a)

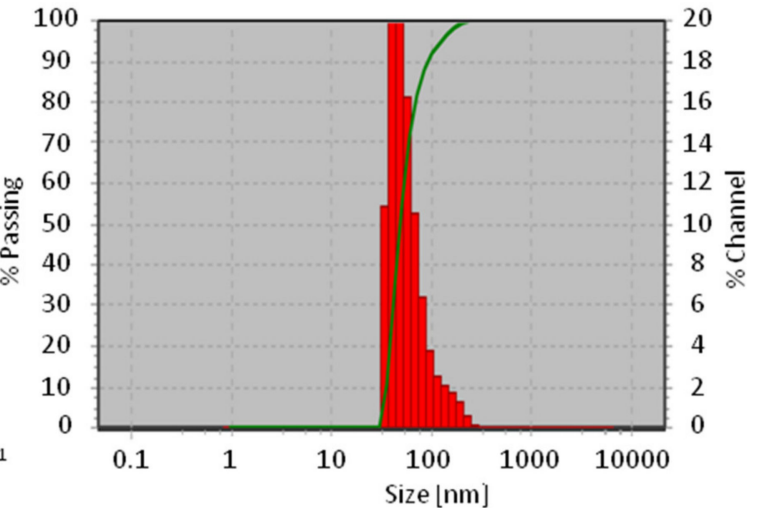

(b)

Figure 3. Results of $\mathrm{SiO}_{2}$ particle size measurement by (a) spectroacoustic study (1-after sonication; 2-before sonication) and (b) dynamic light scattering (sonicated). In (b) x-axis: particle size, $\mathrm{nm}$. Y-axis: left-the fraction of particles with a diameter at least this, \% (line); right-the fraction of particles in the size range, \% (histogram).

Thus, based on the determination of $\mathrm{SiO}_{2}$ particle size and shape by four independent methods, it was found that the sample was presented by NM. 


\subsection{Subacute 92-Day Experiment on Non-Immunized Animals}

\subsubsection{Condition and Growth of Animals during the Experiment}

During the first month of intragastric administration of $\mathrm{SiO}_{2}$ suspension to animals, the death of one rat occurred in group 4, and three occurred in group 5. The autopsy of dead animals showed the signs of bilateral pneumonia, as might be expected due to accidental aspiration of NM's traces when administering by gavage of a suspension containing a high concentration of NPs. The presence of inhalation toxicity in $\mathrm{SiO}_{2} \mathrm{NPs}$ is known from the data of [2,3]. Furthermore, one rat died in group 3 in the third month of the experiment. Other animals of all experimental groups had normal appearances regarding the coat, mucousal surfaces, locomotor activity, behavior, and stool, and did not differ in this respect from the control group. Determination of average monthly increases of bw as follows from data presented in Figure 4 showed that during the first and second months of the experiment, the animals of all groups gained weight at almost the same rate $(p>0.1$, ANOVA). However, after the third month, there was a slight (not more than 15\%) but significant delay in weight gain in all experimental groups compared to the control. This effect was not dose-dependent and was probably associated in aged animals with a reduction of fat mass gain, which cannot be interpreted as a sign of unfavorable (toxic) activities of $\mathrm{SiO}_{2}$ administration.

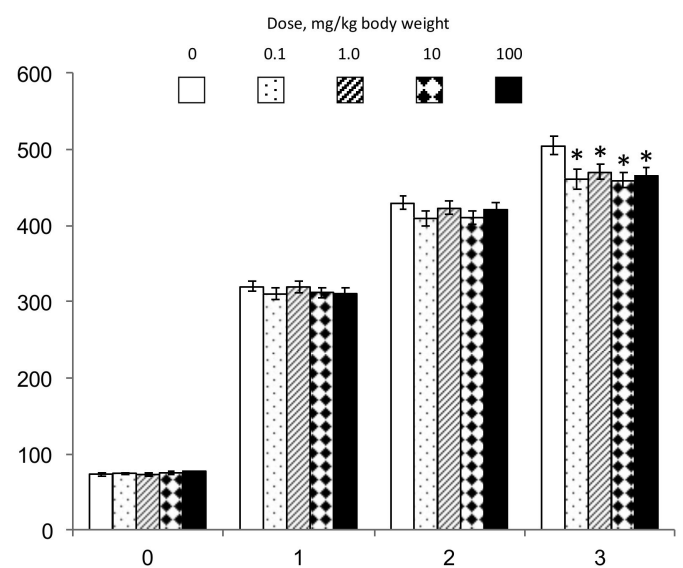

(a)

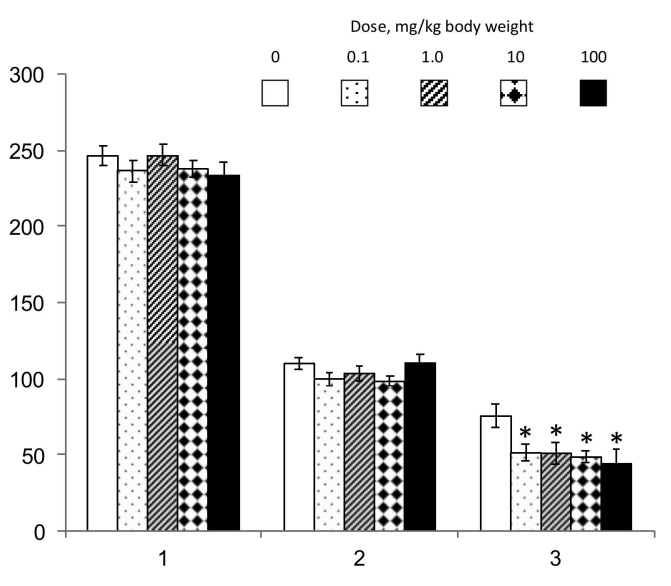

(b)

Figure 4. Average body weight (a) and monthly weight gain (b) of rats in groups 1-5 during the experiment. The $x$-axis—time, months; $y$-axis—the average body weight (a) or the average increase of body weight $(\mathbf{b}) ;{ }^{*}$ - difference with group 1 is significant, $p<0.05$, Mann-Whitney $U$.

\subsubsection{Weights of Internal Organs}

The data presented in Table 1 show the relative weights of internal organs expressed as percentages of body weight. No changes in the weight of the majority of the internal organs related to $\mathrm{SiO}_{2}$ dose were observed. The exception was the adrenal glands, whose mass was significantly $(p<0.05)$ increased in groups 3 and 4 compared with group 1, a maximum of $32 \%$. In group 5, receiving the highest dose of NM, this effect was not displayed, so it is not dose-dependent. 
Table 1. Relative weights of rats' internal organs in groups 1-5 on the 93rd day of the experiment.

\begin{tabular}{|c|c|c|c|c|c|c|c|c|c|c|}
\hline \multirow{2}{*}{ Groups } & \multirow{2}{*}{$\begin{array}{c}\mathrm{SiO}_{2} \text { Dose, } \\
\mathrm{mg} / \mathrm{kg} \text { Body Weight }\end{array}$} & \multirow{2}{*}{$\begin{array}{c}\text { Number } \\
\text { of Animals }\end{array}$} & \multicolumn{8}{|c|}{ Mass of Internals, $\%$ of Body Weight, $M \pm$ s.e.m. } \\
\hline & & & Liver & Kidneys & Spleen & Testis & Heart & Thymus & Lungs & Adrenals \\
\hline 1 & 0 & 9 & $2.77 \pm 0.06$ & $0.628 \pm 0.017$ & $0.347 \pm 0.018$ & $0.737 \pm 0.029$ & $0.284 \pm 0.009$ & $0.139 \pm 0.008$ & $0.476 \pm 0.013$ & $0.022 \pm 0.001$ \\
\hline 2 & 0.1 & 10 & $2.67 \pm 0.16$ & $0.631 \pm 0.036$ & $0.321 \pm 0.018$ & $0.733 \pm 0.026$ & $0.274 \pm 0.013$ & $0.131 \pm 0.012$ & $0.493 \pm 0.027$ & $0.024 \pm 0.003$ \\
\hline 3 & 1.0 & 9 & $2.65 \pm 0.06$ & $0.643 \pm 0.018$ & $0.347 \pm 0.024$ & $0.770 \pm 0.016$ & $0.266 \pm 0.005$ & $0.142 \pm 0.006$ & $0.501 \pm 0.014$ & $0.028 \pm 0.001 *$ \\
\hline 4 & 10 & 9 & $2.59 \pm 0.07$ & $0.629 \pm 0.015$ & $0.321 \pm 0.007$ & $0.822 \pm 0.040$ & $0.268 \pm 0.006$ & $0.156 \pm 0.006$ & $0.477 \pm 0.020$ & $0.029 \pm 0.002 *$ \\
\hline 5 & 100 & 7 & $2.71 \pm 0.04$ & $0.639 \pm 0.016$ & $0.306 \pm 0.015$ & $0.769 \pm 0.025$ & $0.280 \pm 0.009$ & $0.130 \pm 0.011$ & $0.480 \pm 0.019$ & $0.027 \pm 0.002$ \\
\hline \multicolumn{3}{|c|}{ Homogeneity of distribution in groups $1-5$, ANOVA } & $\begin{array}{c}p>0.05 \\
F=0.446\end{array}$ & $\begin{array}{c}p>0.05 \\
F=0.083\end{array}$ & $\begin{array}{c}p>0.05 \\
F=0.969\end{array}$ & $\begin{array}{c}p>0.05 \\
F=1.644\end{array}$ & $\begin{array}{c}p>0.05 \\
F=0.768\end{array}$ & $\begin{array}{c}p>0.05 \\
F=1.363\end{array}$ & $\begin{array}{c}p>0.05 \\
F=0.330\end{array}$ & $\begin{array}{c}p>0.05 \\
F=1.730\end{array}$ \\
\hline
\end{tabular}

${ }^{1}$ From each group of animals in this experiment, 5 rats were removed from the study for examination of metabolomic and proteomic parameters of the liver; the experimental methodology used therein did not allow including these animals in the data presented in this study. ${ }^{*}$-Difference with group 1 is significant, $p<0.05$, Mann-Whitney $U$. 


\subsubsection{The Intestinal Barrier Permeability}

Orally administered NPs of some species may have an irritating effect and induce inflammation in the wall of the small intestine. Given this, it was of interest to find out whether nanostructured $\mathrm{SiO}_{2}$ is capable of affecting the permeability of the intestinal barrier for protein macromolecules. The data presented in Figure 5 show that no significant changes were observed in the absorption of macromolecular proteins into the blood in animals that received NPs for three months at a dose of up to $100 \mathrm{mg} / \mathrm{kg}$ of bw

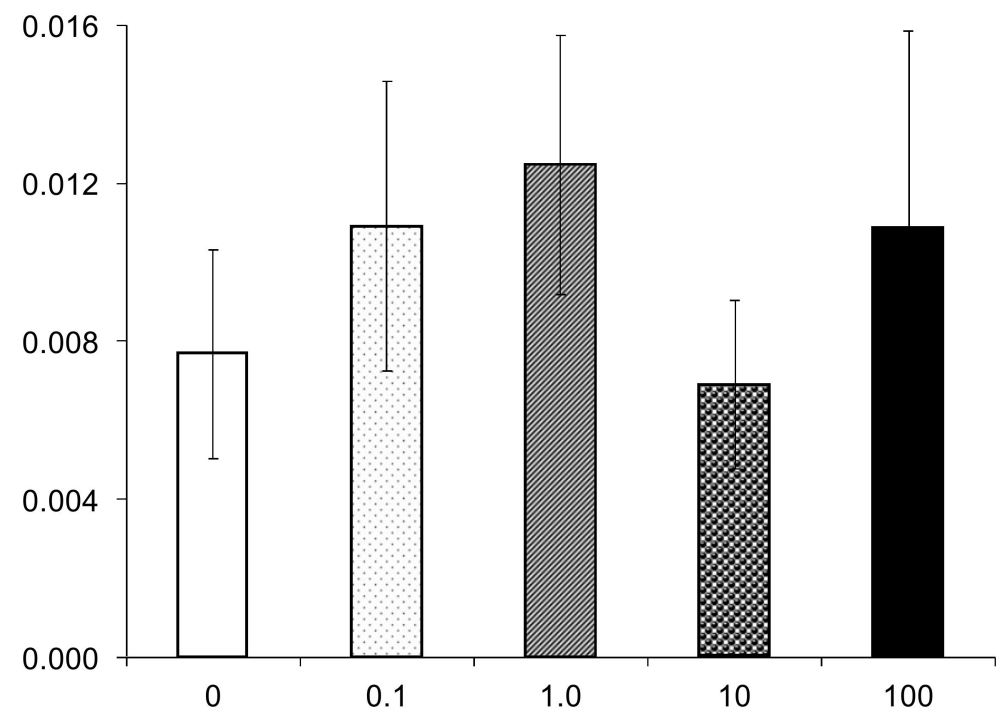

Figure 5. Data characterizing the permeability of the intestinal barrier for macromolecules of protein (OVA) in rats of groups 1-5. X-axis-dose of $\mathrm{SiO}_{2} \mathrm{NPs}, \mathrm{mg} / \mathrm{kg}$ bw. Y-axis-absorption of OVA macromolecules into the blood, percentage of the administered dose $\times 10^{3}, M \pm$ s.e.m. Data distribution in group is homogeneous (ANOVA $F=0.504 ; p>0.1$ ). Paired differences between groups are insignificant, $p>0.1$, Mann-Whitney test.

\subsubsection{Hematological Indices}

The results of hematological parameter determination in animals of groups $1-5$ are shown in Tables 2 and 3. As follows from the data, rats of fourth group had a significant $(p<0.05)$ decrease in the number of red blood cells $(5 \%)$, which was accompanied by significant $(p<0.05)$ increases in the average volume of red blood cells and hemoglobin content. A small (5\%) but significant increase in the mean corpuscular volume of erythrocytes was also observed in the animals of group 5. Other parameters had no significant changes from the data from the remaining experimental groups of animals. There were no changes in the parameters characterizing the state of platelets in animals $(p>0.05$ for all indicators; data not shown). Thus, even in the highest dose, the magnitude and direction of identified changes in the state of erythrocytes and platelets of animals do not indicate any adverse impact of nanostructured $\mathrm{SiO}_{2}$ on blood. Indicators of blood leukocytes (Table 3) did not differ in animals of groups $2-5$ from the control, except for a significant $(p \leq 0.05)$ and quite pronounced $(33 \%)$ decrease in the total number of leukocytes in rats of group 5 . 
Table 2. Erythrocyte indices in groups 1-5 on the 93rd day of the experiment.

\begin{tabular}{|c|c|c|c|c|c|c|c|}
\hline \multirow[b]{2}{*}{ Groups } & \multirow[b]{2}{*}{$\begin{array}{c}\text { Number } \\
\text { of Animals }{ }^{1}\end{array}$} & \multicolumn{6}{|c|}{ Indices, $M \pm$ s.e.m. } \\
\hline & & $\begin{array}{l}\text { Number of } \\
\text { Erythrocytes, } \\
10^{12} / \mathrm{dm}^{3}\end{array}$ & $\begin{array}{c}\text { Hemoglobin } \\
\text { Concentration, } \\
\mathrm{g} / \mathrm{dm}^{3}\end{array}$ & Hematocrit, \% & $\begin{array}{l}\text { Mean Volume of } \\
\text { Erythrocyte, } \mu \mathrm{m}^{3}\end{array}$ & $\begin{array}{l}\text { Mean Content of } \\
\text { Hemoglobin in } \\
\text { Erythrocyte, pg }\end{array}$ & $\begin{array}{c}\text { Hemoglobin } \\
\text { Concentration } \\
\text { in Cells, } \mathrm{g} / \mathrm{dm}^{3}\end{array}$ \\
\hline 1 & 9 & $8.63 \pm 0.17$ & $147.7 \pm 2.5$ & $42.73 \pm 0.80$ & $49.56 \pm 0.87$ & $17.12 \pm 0.32$ & $345.8 \pm 2.2$ \\
\hline 2 & 10 & $8.33 \pm 0.11$ & $145.3 \pm 1.5$ & $41.72 \pm 0.55$ & $49.90 \pm 0.48$ & $17.43 \pm 0.12$ & $348.1 \pm 2.3$ \\
\hline 3 & 9 & $8.27 \pm 0.10$ & $143.8 \pm 3.5$ & $41.91 \pm 1.10$ & $50.67 \pm 0.87$ & $17.33 \pm 0.26$ & $342.7 \pm 2.0$ \\
\hline 4 & 9 & $8.15 \pm 0.09$ & $147.4 \pm 1.9$ & $43.01 \pm 0.49$ & $52.89 \pm 0.54$ & $18.11 \pm 0.25$ & $342.8 \pm 2.6$ \\
\hline 5 & 7 & $8.43 \pm 0.14$ & $150.1 \pm 2.4$ & $44.01 \pm 0.64$ & $52.29 \pm 0.78$ & $17.81 \pm 0.30$ & $340.9 \pm 1.5$ \\
\hline \multicolumn{2}{|c|}{ Homogeneity of distribution in groups $1-5$, ANOVA, $p$ ( $F$ value) } & $>0.05(2.252)$ & $>0.05(0.922)$ & $>0.05(1.387)$ & $0.006(4.198)$ & $>0.05(2.461)$ & $>0.05$ (1.693) \\
\hline \multirow{4}{*}{ Significance * compared to group $1, p$} & Group 2 & $>0.05 />0.05$ & $>0.05 />0.05$ & $>0.05 />0.05$ & $>0.05 />0.05$ & $>0.05 />0.05$ & $>0.05 />0.05$ \\
\hline & Group 3 & $>0.05 />0.05$ & $>0.05 />0.05$ & $>0.05 />0.05$ & $>0.05 />0.05$ & $>0.05 />0.05$ & $>0.05 />0.05$ \\
\hline & Group 4 & $0.020 / 0.031$ & $>0.05 />0.05$ & $>0.05 />0.05$ & $0.005 / 0.008$ & $0.026 / 0.027$ & $>0.05 />0.05$ \\
\hline & Group 5 & $>0.05 />0.05$ & $>0.05 />0.05$ & $0.039 />0.05$ & $0.039 / 0.043$ & $>0.05 />0.05$ & $>0.05 />0.05$ \\
\hline
\end{tabular}

${ }^{1}$-See comment in Table 1; *-Student's T (numerator); Mann-Whitney $U$ (denominator)

Table 3. Leucocyte counts in groups 1-5 on the 93rd day of the experiment.

\begin{tabular}{|c|c|c|c|c|c|c|c|c|}
\hline \multirow{2}{*}{ Groups } & \multirow{2}{*}{$\begin{array}{l}\text { Number } \\
\text { of Animals }\end{array}$} & \multicolumn{7}{|c|}{ Indices, $M \pm$ s.e.m. } \\
\hline & & Total Leucocytes, $10^{9} / \mathrm{dm}^{3}$ & Neutrophils, $\%$ & Eosinophiles, \% & Basophiles, \% & Lymphocytes, \% & Monocytes, \% & Immature Cells, \% \\
\hline 1 & 9 & $16.79 \pm 1.18$ & $18.11 \pm 1.54$ & $2.30 \pm 0.41$ & $0.29 \pm 0.04$ & $70.21 \pm 2.15$ & $9.00 \pm 0.96$ & $0.73 \pm 0.09$ \\
\hline 2 & 10 & $15.10 \pm 1.55$ & $20.52 \pm 1.58$ & $2.69 \pm 0.42$ & $0.28 \pm 0.05$ & $67.47 \pm 1.80$ & $8.79 \pm 1.15$ & $0.95 \pm 0.12$ \\
\hline 3 & 9 & $15.72 \pm 1.38$ & $19.70 \pm 1.99$ & $2.56 \pm 0.25$ & $0.28 \pm 0.03$ & $70.59 \pm 1.91$ & $7.54 \pm 0.46$ & $0.89 \pm 0.14$ \\
\hline 4 & 9 & $16.37 \pm 1.48$ & $20.41 \pm 1.91$ & $2.63 \pm 0.27$ & $0.32 \pm 0.07$ & $68.24 \pm 2.03$ & $8.20 \pm 0.93$ & $0.91 \pm 0.13$ \\
\hline 5 & 7 & $11.21 \pm 2.01$ & $24.10 \pm 2.65$ & $2.47 \pm 0.44$ & $0.30 \pm 0.02$ & $65.43 \pm 2.51$ & $7.51 \pm 0.49$ & $0.91 \pm 0.18$ \\
\hline \multicolumn{2}{|c|}{$\begin{array}{l}\text { Homogeneity of distribution in } \\
\text { groups } 1-5 \text {, ANOVA, } p(F \text { value })\end{array}$} & $>0.05(1.861)$ & $>0.05(1.160)$ & $>0.05(0.180)$ & $>0.05(0.143)$ & $>0.05(0.960)$ & $>0.05(0.580)$ & $>0.05(0.428)$ \\
\hline \multirow{4}{*}{$\begin{array}{l}\text { Significance* } \\
\text { compared to } \\
\text { group } 1, p\end{array}$} & Group 2 & $>0.05 />0.05$ & $>0.05 />0.05$ & $>0.05 />0.05$ & $>0.05 />0.05$ & $>0.05 />0.05$ & $>0.05 />0.05$ & $>0.05 />0.05$ \\
\hline & Group 3 & $>0.05 />0.05$ & $>0.05 />0.05$ & $>0.05 />0.05$ & $>0.05 />0.05$ & $>0.05 />0.05$ & $>0.05 />0.05$ & $>0.05 />0.05$ \\
\hline & Group 4 & $>0.05 />0.05$ & $>0.05 />0.05$ & $>0.05 />0.05$ & $>0.05 />0.05$ & $>0.05 />0.05$ & $>0.05 />0.05$ & $>0.05 />0.05$ \\
\hline & Group 5 & $0.025 / 0.050$ & $>0.05 />0.05$ & $>0.05 />0.05$ & $>0.05 />0.05$ & $>0.05 />0.05$ & $>0.05 />0.05$ & $>0.05 />0.05$ \\
\hline
\end{tabular}

*-Student's T (numerator); Mann-Whitney $U$ (denominator). 


\subsubsection{Immunological Parameters in Non-Immunized Animals}

Although the relative number of lymphocytes (Ly) in the total population of leukocytes shows an only slight (7\%) and nonsignificant decrease in animals of group 5 , the qualitative composition of Ly, as can be seen from the data presented in Figure 6, was substantially modified. Particularly, the proportion of Th cells (13\%) was significantly reduced, and Tregs were more common (19\%); all of that led to the decrease $(27 \%)$ in the immunoregulatory index. In combination with the general decline in the number of identified leukocytes, this indicates a significant weakening of the T-cell immunity in the 5th group receiving the highest doses of $\mathrm{SiO}_{2} \mathrm{NPs}$. This observation is supported by data on the occurrence of an imbalance in levels of the main group of pro- and anti-inflammatory cytokines, particularly TNF- $\alpha$, whose content was significantly increased by an average of $590 \%$, and IL-10, the content of which exhibited a pronounced (36\%) tendency toward reduction. It can be assumed that the detected decrease in Th cells extends mainly to the Th1 population. IL-6 levels in the blood of animals in all groups remained below the detection limit of the method (data not shown). Thus, the NOAEL level for nanostructured $\mathrm{SiO}_{2}$ in terms of hematological and immunological indices was within the range of $10-100 \mathrm{mg} / \mathrm{kg}$ body weight.

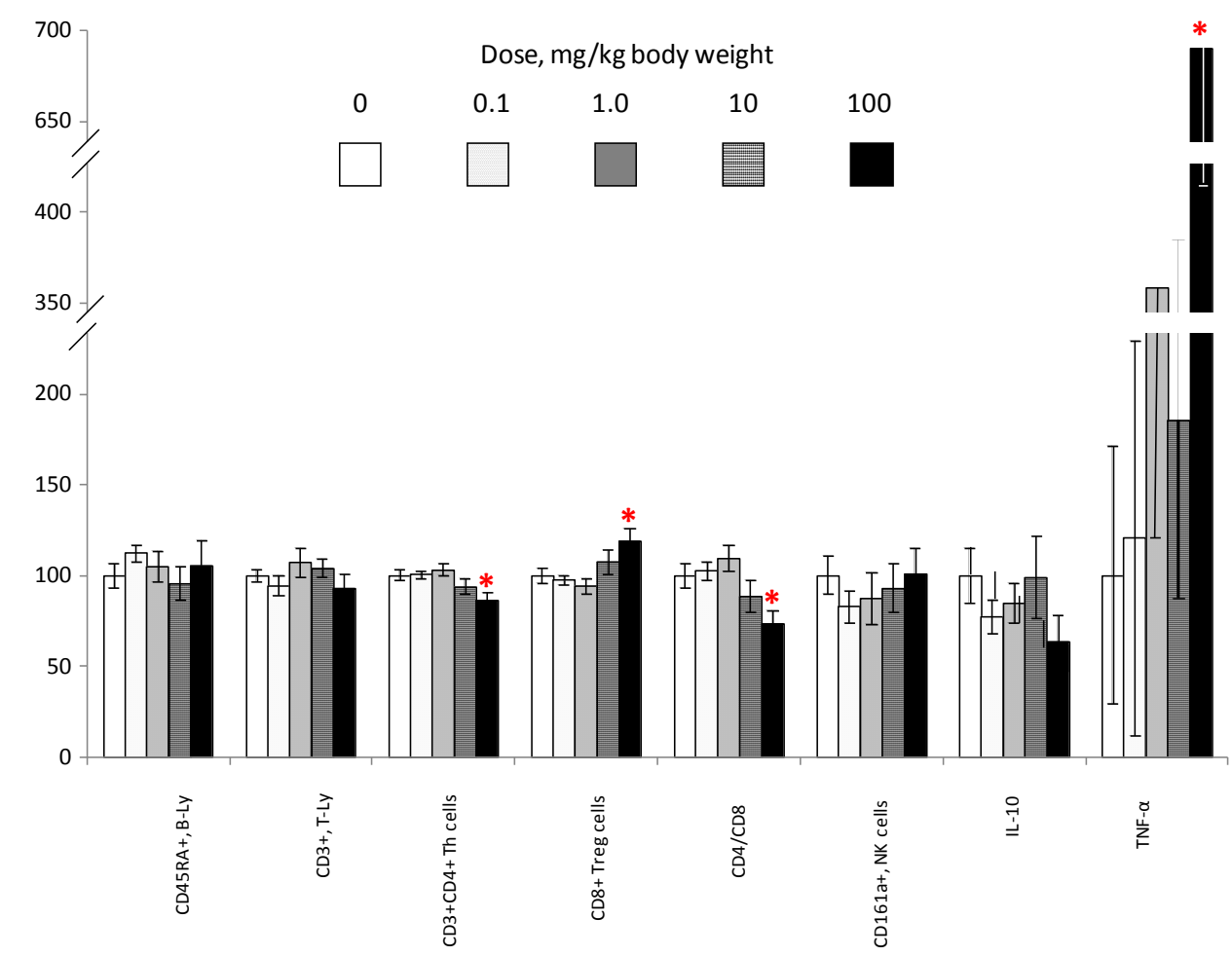

Figure 6. Key indicators of the cellular immunity in rats of 1-5 groups. X-axis-name of indicators, number of samples; $y$-axis—-the values in percent of the control group (group 1), $M \pm$ s.e.m. *-Difference with group 1 is significant, Student's $T$ and Mann-Whitney $U$.

\subsection{Twenty-Eight-Day Experiment on Immunized Animals}

It is also of interest to establish the effect of oral administration of nanostructured silica on the performance of the immune system in animals under the conditions of the food allergen immunization model, reproduced with OVA immunization. The period selection of NM administration to animals (28 days) was due to the time of development of allergic immunization in the applied standard model of systemic anaphylaxis [14]. During the 28 days of $\mathrm{SiO}_{2}$ administration, one rat died in the second group and one in the sixth group. The autopsy showed signs of bilateral pneumonia, which could have been due to accidental aspiration of the NP suspension in the respiratory tract. The remaining animals had normal appearances, activity, and stool. As can be seen from the data presented in Table 4, 
the average body weight gains of rats in the first and second groups at the end of the experiment were not significantly different. The data on the severity of the systemic anaphylaxis reaction (Table 4) indicate that in animals that received $\mathrm{SiO}_{2} \mathrm{NPs}$ at a dose of $100 \mathrm{mg} / \mathrm{kg}$ bw per day for a month, an increase in the severity of the allergic reaction was observed, which, however, remained statistically insignificant $(p>0.05)$. The same can be noted in the level of IgG antibodies to OVA, expressed by three different parameters (Table 4). The distributions of animals in groups 1 and 2 by the severity of the anaphylaxis reaction, expressed in points, differed statistically insignificantly $(p>0.05$, chi-square). Thus, the effect of enhancing immunization by food allergen OVA was weak (marginally) in animals exposed to $\mathrm{SiO}_{2}$ NPs at a dose of $100 \mathrm{mg} / \mathrm{kg}$ bw; therefore, this level can be considered as the upper limit of NOAEL.

Table 4. Comparison of body weight gain, active anaphylactic reaction (AAR) indices, and antibody response in rats of groups 1 and 2 immunized with ovalbumin (OVA).

\begin{tabular}{|c|c|c|c|c|}
\hline \multirow[b]{2}{*}{ Indices, Units } & \multicolumn{2}{|c|}{ Number of Animals } & \multirow[b]{2}{*}{ Significance, $p$} & \multirow[b]{2}{*}{ Comment } \\
\hline & $\begin{array}{c}\text { Group } 1 \\
(\mathrm{~N}=24) * * * *\end{array}$ & $\begin{array}{l}\text { Group } 2 \\
(\mathrm{~N}=25)\end{array}$ & & \\
\hline Body weight, g, $M \pm$ s.e.m. & $295.5 \pm 4.4$ & $284.7 \pm 4.2$ & $>0.05^{*}$ & - \\
\hline AAR, lethality (4+), \% & 33.0 & 48.0 & $>0.05^{* *}$ & - \\
\hline $\begin{array}{l}\text { AAR, heavy reactions } \\
(3+\text { and } 4+), \%\end{array}$ & 33.0 & 48.0 & $>0.05^{* *}$ & $\begin{array}{l}\text { All animals with } \\
\text { heavy AAR died }\end{array}$ \\
\hline $\begin{array}{l}\text { Anaphylactic index } \\
\text { (mean score of AAR) }\end{array}$ & 2.29 & 2.44 & $>0.05^{* * *}$ & - \\
\hline Level of IgG to OVA, $\mathrm{mg} / \mathrm{cm}^{3}, M \pm$ s.e.m. & $5.53 \pm 0.90$ & $6.14 \pm 0.98$ & $\begin{array}{c}>0.05^{*} \\
>0.05^{* * *}\end{array}$ & - \\
\hline $\begin{array}{l}\text { Level of IgG to OVA, optical density units } \\
\text { at } 492 \mathrm{~nm}, M \pm \text { s.e.m. }\end{array}$ & $1.316 \pm 0.043$ & $1.345 \pm 0.038$ & $\begin{array}{l}>0.05^{*} \\
>0.05^{* * *}\end{array}$ & - \\
\hline $\lg [$ level of IgG to OVA] & $0.580 \pm 0.088$ & $0.637 \pm 0.081$ & $\begin{array}{l}>0.05^{*} \\
>0.05^{* * *}\end{array}$ & \\
\hline
\end{tabular}

*-Student's T; **-Criterion $U$ Fisher's angular transformation; ${ }^{* * *-M a n n-W h i t n e y ~} U$; ${ }^{* * * *}$ One animal in group 1 was not challenged (i.v. injection of antigen failed).

Average indices characterizing the state of erythrocytes in rats of groups 3-6 only slightly (3-5\%) differed between groups (data not shown). There were slight but significant $(p<0.05$, ANOVA) reductions in the concentration of hemoglobin (4\%) and the erythrocyte count (3\%) in the blood of immunized animals (groups 3 and 4) when compared to non-immunized (groups 5 and 6). No influence of NM on the states of erythrocytes and platelets was found in immunized or non-immunized animals. The study of leukocyte counts showed that immunization and monthly administration of NM did not have any impact on these indicators, except for a significant $(p<0.05)$ increase in the number of total Ly by $8 \%$ due to immunization against the introduction of $\mathrm{SiO}_{2} \mathrm{NPs}$. It can be assumed from Table 5 that the reason for this increase was probably growth in the number of B cells, the proportion of which in the total pool in immunized animals treated with NPs increased. In the absence of NPs treatment, a similar effect was not observed.

When assessing the parameters of the cellular immune system of animals (Table 5), it can be concluded that both 3-month and 1-month administration of $\mathrm{SiO}_{2} \mathrm{NPs}$ at a dose of $100 \mathrm{mg} / \mathrm{kg}$ bw in non-immunized animals leads to a significant reduction of T-helper cells, increasing the number of cytotoxic T-Ly and reducing the CD4/CD8 ratio. However, these changes are "fuzzy" against the background of immunization and acquire the character of a statistically insignificant trend. Thus, strengthening of $\mathrm{SiO}_{2}$ immunotoxic properties in the conditions of food protein immunization was at least not observed. Noteworthy is the significant $(p<0.05)$ and a very pronounced $(75 \%)$ increase in the number of natural killer cells (CD161a+) as a result of exposure to NPs in non-immunized animals. Against the background of immunization, this effect apparently does not occur. However, these changes can be considered as the activation of nonspecific cellular immunity under the influence of NPs, which cannot be unambiguously interpreted as negative (harmful). Therefore, sufficient reason is absent to reduce the range of NOAEL in the condition of immunization. 
Table 5. Cellular immunity indices in rat groups 3-6 on the 29th day of the experiment.

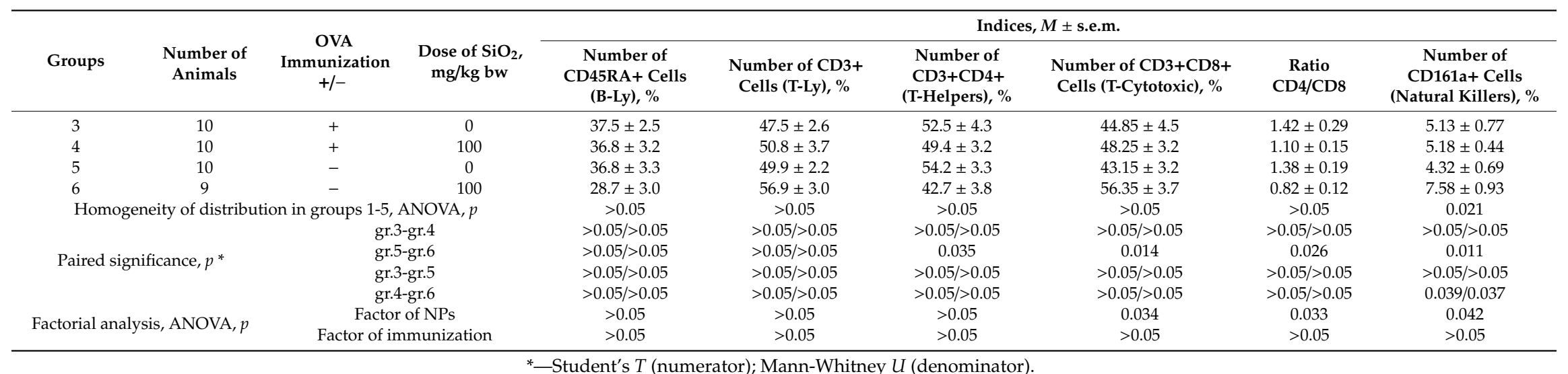


Basal indices of the activity of phagocytosis of neutrophilic leukocytes in rats of groups 3-6 did not differ (data not shown). The stimulation index of phagocytosis by the action of PMA showed a tendency to decrease in group 6 under $\mathrm{SiO}_{2}$ action in the absence of immunization; the difference with 5th group, however, was insignificant $(p>0.05)$. When comparing similar groups of immunized animals (third and fourth), said effect was apparently not noticeable. Factor analysis showed the absence of any influence on phagocytosis both under immunization and under NM consumption.

Analysis of cytokine levels in the sera of animals showed that there is a tendency to reduce the IL-10 concentration upon administration of $\mathrm{SiO}_{2} \mathrm{NPs}$ in immunized rats $(41 \%)$, and one toward an increase in the TNF- $\alpha$ level in unimmunized rats ( $28 \%$, data not shown). However, these differences were not significant $(p>0.05)$. It can be assumed that the 28-day period of NM administration was apparently insufficient to develop pronounced effects on cytokine production, which were identified in a three-month experiment.

Thus, the 28-day administration of nanostructured $\mathrm{SiO}_{2}$ at a dose of $100 \mathrm{mg} / \mathrm{kg}$ bw, which was the largest studied, does not lead to a significant increase in allergic sensitivity against a food allergen. On the other hand, potentially unfavorable changes in the immune system, observed at the highest dose of NM, particularly the balance of CD4+ and CD8+ cells, are at least not increased on the background of immunization. Thus, the data of the immunological and allergy study in immunized animals did not give reasons for the revision of the NOAEL level, established in experiments on non-immunized animals.

\section{Discussion}

In this work, the study of the effect of nanostructured $\mathrm{SiO}_{2}$ administered orally to rats on some biological indicators of toxicity, including the parameters of the cellular immune system, was carried out in the dose range from 1 to $100 \mathrm{mg} / \mathrm{kg}$ of bw in a subacute 92-day experiment. According to a previous evaluation [6], the daily load of $\mathrm{SiO}_{2} \mathrm{NPs}$ from food on a person can reach $1.8 \mathrm{mg} / \mathrm{kg}$ of bw, which is close to the minimum daily dose used in our present study. The maximum 100-fold aggravated dose of $\mathrm{NM}$ was at least 50 times lower than the corresponding $\mathrm{LD}_{50}$, which was estimated at $5000 \mathrm{mg} / \mathrm{kg} \mathrm{bw}$. Further aggravation of $\mathrm{SiO}_{2}$ dose in this experiment was not possible, as this greatly increased the risk of the animals' death due to the aspiration of the suspension traces during the first month of administration.

The data obtained in hematological and immunological studies showed that the administration to animals of nanostructured $\mathrm{SiO}_{2}$ at a dose of at least $100 \mathrm{mg} / \mathrm{kg}$ bw led to a noticeable shift in the parameters of the immune system, which may indicate the manifestation of a certain toxic effect. This result is consistent with many published data on the toxicity of silica NPs.

According to in vitro studies, amorphous $\mathrm{SiO}_{2} \mathrm{NPs}$ have various toxic properties. The adverse effect of NPs may be based on the catalytic generation of free radical compounds found in the cell-free system [17], in cultured keratinocytes [18], and human alveolar epithelial cells [19]. Cytotoxic effects of $\mathrm{SiO}_{2} \mathrm{NPs}$ for the EAHY926 cell line were observed in a study [20]. Under the same conditions, submicron particles (100-330 nm) were not toxic. In the culture of mouse embryonic stem cells, amorphous $\mathrm{SiO}_{2}$ NPs 10 and 30 (but not 80) nm in diameter suppressed differentiation into normal cardiomyocytes [21]. Apoptosis and changes in the expression of p53, Bax, and Bcl-2 were found in normal liver cells of the L-02 line under the action of $21 \mathrm{~nm} \mathrm{SiO}{ }_{2} \mathrm{NPs}$ [22]. The presence of various cytotoxic properties in $\mathrm{SiO}_{2} \mathrm{NPs}$ was also revealed in the works [23-25]. There is also some evidence on the organotoxic action of silica NPs in vivo. Hence, a cardiotoxic effect was observed after the parenteral administration of silica NPs to zebrafish embryos, which manifested in inflammation of the heart muscle, mediated by suppression of the transcriptional activity of the genes ATPases, calcium channels, and troponin C [26].

According to a number of studies, NPs of different types [27-31] can be absorbed in the digestive tract, thereby entering the circulatory and lymphatic systems. The quantitative assessment of the absorption and bioavailability of $\mathrm{SiO}_{2} \mathrm{NPs}$ is a difficult task due to the lack of methods for detecting 
these NPs in complex matrixes [32]. In [6], for the first time, indirect evidence was obtained for the accumulation of silicon in the liver after 84-day intragastric administration of $\mathrm{SiO}_{2} \mathrm{NPs}$ to rats. Unfortunately, the authors used the ICP-MS method, which made it impossible to estimate the size of accumulating NPs. In addition, high background levels of silicon in animal tissues made it impossible to rigorously quantify this indicator. A number of in vivo studies have shown that nanostructured amorphous $\mathrm{SiO}_{2}$ exhibits inhalation toxicity [2,3]. However, the study of the effects of $\mathrm{SiO}_{2} \mathrm{NPs}$ after oral administration has led to contradictive results. Intragastric administration of nanostructured amorphous $\mathrm{SiO}_{2}$ to rats at a dose of $170-1500 \mathrm{mg} / \mathrm{kg}$ bw within 90 days did not cause pronounced toxic effects, which, apparently, was studied by a complex of biochemical, physiological, hematological, and allergological parameters [7]. After the exposure of zebrafish eggs to silica NPs, no subsequent occurrence of anomalies in the development of embryos, or signs of cardio- and hepatotoxicity was revealed, although there were some features in behavioral reactions [33]. Feeding female quails with $\mathrm{SiO}_{2}$ nanoparticles for 10 weeks at a dose of up to $4000 \mathrm{mg}$ per $\mathrm{kg}$ of feed did not lead to significant changes in blood plasma biochemical parameters and histopathological changes in the liver, but caused a decrease in the weight of the yolks of eggs and an increase in the thickness of their shells [34]. Based on the data listed, it may be concluded that the oral toxicity of silica nanoparticles is relatively low. At the same time, in works [3,4], mice in an acute experiment were injected intragastrically with "monodisperse" $\mathrm{SiO}_{2} \mathrm{NPs}$ obtained by the method of the liquid crystal templating using cetyltrimethylammonium bromide as a template. The $\mathrm{SiO}_{2}$ particles used in these studies were elliptical in size of approximately $(50 \sim 70) \times(20 \sim 30) \mathrm{nm}$. In the groups receiving NPs, on days 3 and 4 , the death of animals was observed at an $\mathrm{LD}_{50}$ level of $4600 \mathrm{mg} / \mathrm{kg}$ bw. At a dose of $\mathrm{SiO}_{2} \mathrm{NPs}$ higher than $0.2 \times \mathrm{LD}_{50}$, the damage to blood cells was observed, and at a dose of $0.3 \times$ $\mathrm{LD}_{50}$, morphological changes in the circulatory, lymphoid, and macrophage systems, and degenerative changes in the liver and kidneys were seen. The studied $\mathrm{SiO}_{2} \mathrm{NPs}$ were characterized by significant cumulativeness (cumulative index 0.45).

The authors of the article [6] studied the subacute 84-day toxicity of two types of nanostructured silica when administered orally to rats at very high doses $(100-2500 \mathrm{mg} / \mathrm{kg}$ bw daily). Dose-dependent increasing fibrosis in the liver and the expression of genes responsible for this process have been noted. According to these alterations, the authors estimated the lowest observed adverse effect level (LOAEL) for $\mathrm{SiO}_{2} \mathrm{NPs}$ at $2500 \mathrm{mg} / \mathrm{kg}$ bw. However, the performance of the immune system in this study has not been investigated. It can be assumed that the main reason for the discrepancy in results $[6,7]$ and [3,4], was the difference in the properties of the $\mathrm{SiO}_{2}$ preparations used. It should be noted that all types of nanostructured $\mathrm{SiO}_{2}$ studied in [2-7] are not used in consumer goods, including food. The study of subacute oral toxicity of NPs with a primary particle size of 5-30 nm showed the absence of noticeable signs of toxic effects when NM was administered for three months at a dose of up to $100 \mathrm{mg} / \mathrm{kg}$ bw daily by integral indicators, including weight gain, and permeability of the intestinal barrier to macromolecules. The identified single effects (adrenal hypertrophy in animals of the third and fourth groups) were relatively small in magnitude and did not show a clear dose-dependence. The main "target" of orally administered $\mathrm{SiO}_{2} \mathrm{NPs}$ is the immune system-specifically, T-cell immunity. According to [11], it is assumed that the immunotoxic effect of silica NPs is mediated by the formation of active oxygen substances (ROS) that affect the MAPK pathway, the activation of NLRP3 inflammasomes, and Toll-like receptors with the subsequent induction of autophagy and apoptosis of immune cells. As a result, the number of T-helpers decreases, cytotoxic T-lymphocytes increase, the immunoregulatory index decreases, and the levels of circulating TNF- $\alpha$ increase. As is known, TNF- $\alpha$ is a proinflammatory cytokine synthesized by activated macrophages at the early stages of the immune response. It exhibits cytotoxicity and activation of catabolism, and provides many immunoregulatory effects [35,36]. There is evidence, in particular, of its ability to suppress the activity of helper T cell-mediated immunity, which plays a role in the pathogenesis of HIV infection [37]. The revealed increased production of TNF- $\alpha$ under the influence of $\mathrm{SiO}_{2} \mathrm{NPs}(100 \mathrm{mg} / \mathrm{kg} \mathrm{bw})$ can be considered as one of the indicators 
of immunotoxic action together with a decrease in the level of T-helpers and the magnitude of the immunoregulatory index.

One of the possible consequences of the immunotoxic effect of $\mathrm{SiO}_{2} \mathrm{NPs}$ may be an ability to enhance allergic reactions to extraneous antigens, which was found in [11] in the intranasal route of these NPs' administration. However, our attempt to reveal an increase in the allergic reaction to OVA on the model of systemic anaphylaxis under the influence of intragastric intake of $\mathrm{SiO}_{2} \mathrm{NPs}$ was essentially unsuccessful, showing only a marginal effect which was manifested at the level of a statistically insignificant trend. Thus, it can be assumed that oral intake of nanostructured silica does not pose any significant risk of increased allergic reactions.

When discussing the possible mechanisms of $\mathrm{SiO}_{2} \mathrm{NPs}^{\prime}$ action on immune cells in vivo, it should be noted that there are data in the literature on the adverse effects of various NM on immunological and hematological parameters. Among them are increased production of proinflammatory cytokines [38], platelet aggregation [39], and hemolysis [40]. However, these results were obtained in tests in vitro, where the effective dose of NPs can be significantly increased compared to in vivo conditions. When zebrafish embryos were injected into the bloodstream with $\mathrm{SiO}_{2} \mathrm{NPs}$, they reduced the blood flow rate, caused hypercoagulability, increased erythrocyte aggregation, and induced endothelial inflammation mediated by the JAK1/TF signaling pathway [8]. Full-transcriptome analysis in zebrafish embryos subjected to silica NP action showed increased expression of 1107 genes and suppression of 1408 genes, including the genes involved in the regulation of the immune response; and the production of cytokines, such as genes of the JAK-STAT signaling pathway [41]. Intraperitoneal injection of $\mathrm{SiO}_{2} \mathrm{NPs}$ into rats showed shifts in the function of peritoneal macrophages; increased production of signaling molecules such as IL- $1 \beta, \mathrm{TNF}-\alpha$, and NO; and increased gene expression of IL-1 $\beta, T N F-\alpha$, nitric oxide synthase, and cyclooxygenase-2 [42]. According to [2], inhalation of $\mathrm{SiO}_{2}$ NPs in mice caused pulmonary neutrophilia, accompanied by increased expression of TNF- $\alpha$ and neutrophil-attracting chemokine CXCL1 in the lung tissue. $\mathrm{SiO}_{2} \mathrm{NPs}$ were also able to enhance the allergic immunization with OVA during intranasal [11] and inhalation [43] treatment of mice and rats. In parenteral administration, some oxide NPs activate the kallikrein-kinin system [44] or are histamine liberators [45]. The pro-allergenic effect of inhaled NPs-in particular those produced on an industrial scale-must be taken into account when establishing hygienic standards for occupational exposure, while for NPs contained in food and drinking water, these risks seem to be considerably lower.

The data of the publications discussed above leave open the question of how the immunotoxic effect of silica NPs can manifest itself after the oral administration, given the apparently very low systemic bioavailability of these NPs from the gastrointestinal tract [6]. To explain the reactions identified in our investigation, it is useful to take into account the study of Zaitseva et al. [46], which under conditions close or identical to our work, showed a pronounced local immune response in the intestinal mucosa in rats fed with silica NPs, which manifested as massive leukocyte infiltration and the development of local inflammation. It can be assumed that as a result of the local irritating effect of silica NPs, gastrointestinal lymphoid tissue (GALT) is activated, which is accompanied by the release of circulating pro-inflammatory cytokines, which have a systemic immunotoxic effect, similarly to how it is observed for various inflammatory bowel diseases [47]. It should be noted that this hypothetical mechanism of $\mathrm{SiO}_{2} \mathrm{NPs}$ immunotoxic action does not necessarily require their translocation into internal organs in significant quantities (Figure 7). 


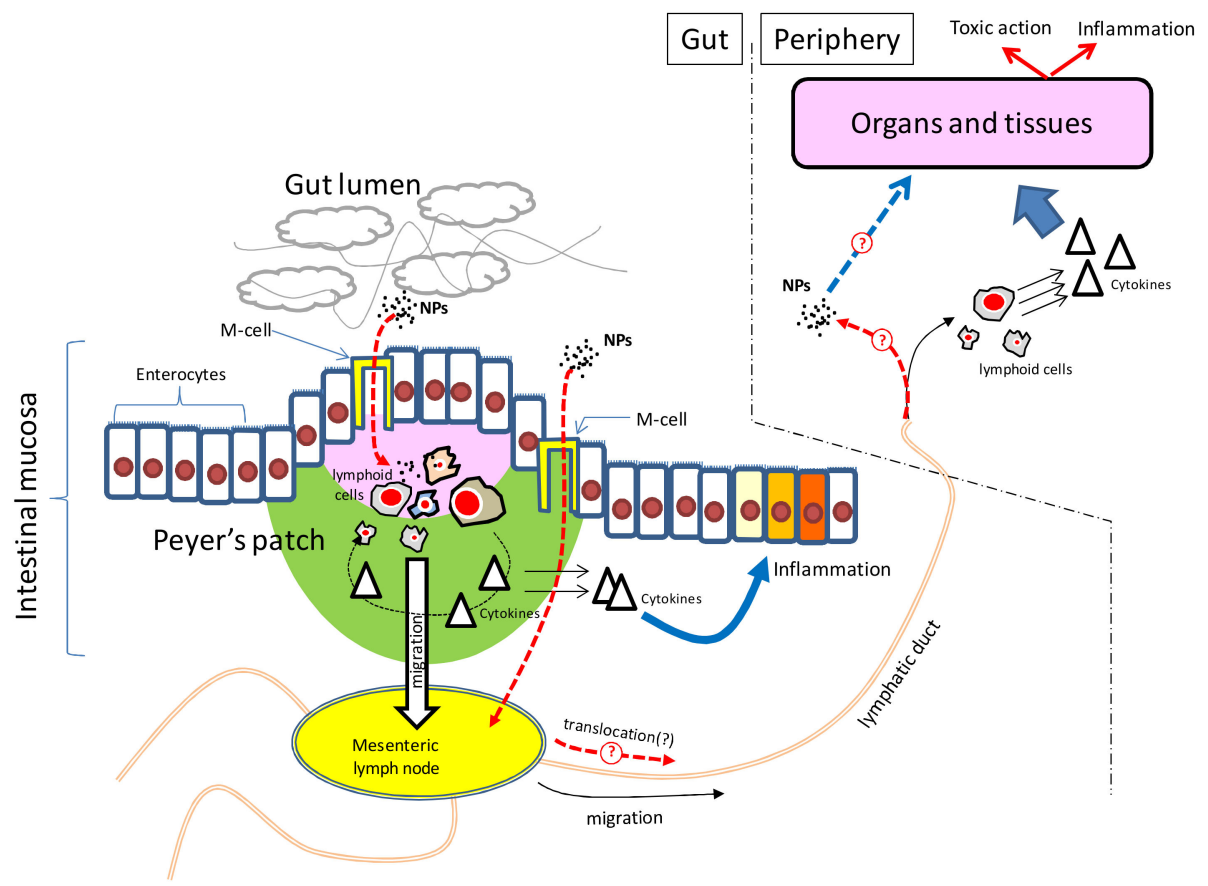

Figure 7. Hypothetical mechanism of $\mathrm{SiO}_{2} \mathrm{NPs}$ ' immunotoxic action at an oral way of administration.

\section{Conclusions}

Thus, $\mathrm{SiO}_{2}$ NPs in subacute oral administration to rats lasting up to three months showed effects on the cellular components of the immune system that were, firstly, clearly dose-dependent, i.e., manifesting to the greatest extent at the highest dose; and secondly, indicated by their direction (in particular, reduced the number of T-helper cells and increased production of pro-inflammatory TNF- $\alpha$ ) the presence of the toxic action. A lack of significant shifts of these parameters in the group of animals treated with studied NM at a dose of $10 \mathrm{mg} / \mathrm{kg}$ bw allowed us to conclude that NOAEL for nanostructured $\mathrm{SiO}_{2}$ ranges up to $100 \mathrm{mg} / \mathrm{kg}$ bw per day in terms of its daily intakes for 1-3 months. This result indicates that the use of nanostructured silicon dioxide as a food additive, and an ingredient for cosmetic products (such as toothpaste) and pharmaceuticals, must be the subject of hygienic regulations.

Author Contributions: Conceptualization, V.A.T., S.A.K., D.B.N. and I.V.G.; methodology, I.V.G. and S.A.K; formal analysis, I.V.G., V.A.S., A.A.S., E.N.T. and I.V.S.; investigation, I.V.G., V.A.S., A.A.S., E.N.T., I.V.S. and O.K.M.; writing —original draft preparation, I.V.G. and V.A.S.; writing—review and editing, V.A.T., S.A.K., D.B.N. and I.V.G.; visualization, I.V.G.; supervision, S.A.K.; project administration, I.V.G.; funding acquisition, V.A.T., S.A.K. and D.B.N. All authors have read and agreed to the published version of the manuscript.

Funding: The research has been accomplished due to financial support provided for fulfilling a task within the Program for fundamental scientific research (the subjects were approved by the Russian Federation Ministry for Education and Science number 0529-2019-0057 "Developing a system of food products quality and safety including food additives and alcohol drinks manufactured with biotechnologies").

Conflicts of Interest: The authors declare no conflict of interest.

\section{References}

1. Food and Agriculture Organization (FAO). Silicon Dioxide, Amorphous. Residue Monograph Prepared by the Meeting of the Joint FAO/WHO Expert Committee on Food Additives (JECFA), 84th Meeting 2017. Available online: http://www.fao.org/3/CA3117EN/ca3117en.pdf (accessed on 14 August 2020).

2. Rossi, E.M.; Pylkkänen, L.; Koivisto, A.J.; Vippola, M.; Jensen, K.A.; Miettinen, M.; Sirola, K.; Nykäsenoja, H.; Karisola, P.; Stjernvall, T.; et al. Airway exposure to silica-coated $\mathrm{TiO}_{2}$ nanoparticles induces pulmonary neutrophilia in mice. Toxicol. Sci. 2010, 113, 422-433. [CrossRef] [PubMed] 
3. Sayes, C.M.; Reed, K.L.; Glover, K.P.; Swain, K.A.; Ostraat, M.L.; Donner, E.M.; Warheit, D.B. Changing the dose metric for inhalation toxicity studies: Short-term study in rats with engineered aerosolized amorphous silica nanoparticles. Inhal. Toxicol. 2010, 22, 348-354. [CrossRef] [PubMed]

4. Zaitseva, N.V.; Zemlyanova, M.A.; Zvezdin, V.N.; Sayenko, Y.V. Toxicological and hygienic safety assessment of the aqueous suspension of nano-dispersed silicon dioxide, synthesized using liquid-crystal templating. Heal. Risk Anal. 2013, 65-72. [CrossRef]

5. Zaitseva, N.V.; Zemlyanova, M.A.; Lebedinskaya, O.V.; Zvezdin, V.N.; Melekhin, S.V.; Akaf'yeva, T.I. Effect of nanosized silicon dioxide on the structural features of the internal organs of experimental animals. Morfologya (Morphology) 2013, 144, 78-79.

6. Van der Zande, M.; Vandebriel, R.J.; Groot, M.J.; Kramer, E.; Herrera Rivera, Z.E.; Rasmussen, K.; Ossenkoppele, J.S.; Tromp, P.; Gremmer, E.R.; Peters, R.J.B.; et al. Sub-chronic toxicity study in rats orally exposed to nanostructured silica. Part. Fibre Toxicol. 2014, 11, 8. [CrossRef]

7. Liang, C.L.; Xiang, Q.; Cui, W.M.; Fang, J.; Sun, N.N.; Zhang, X.P.; Li, Y.N.; Yang, H.; Yu, Z.; Jia, X.D. Subchronic Oral Toxicity of Silica Nanoparticles and Silica Microparticles in Rats. Biomed. Environ. Sci. 2018, 31, 197-207. [CrossRef]

8. Duan, J.; Liang, S.; Yu, Y.; Li, Y.; Wang, L.; Wu, Z.; Chen, Y.; Miller, M.R.; Sun, Z. Inflammation-coagulation response and thrombotic effects induced by silica nanoparticles in zebrafish embryos. Nanotoxicology 2018, 12, 470-484. [CrossRef]

9. Chen, L.; Liu, J.; Zhang, Y.; Zhang, G.; Kang, Y.; Chen, A.; Feng, X.; Shao, L. The toxicity of silica nanoparticles to the immune system. Nanomedicine (London) 2018, 13, 1939-1962. [CrossRef]

10. Murugadoss, S.; Lison, D.; Godderis, L.; Van Den Brule, S.; Mast, J.; Brassinne, F.; Sebaihi, N.; Hoet, P.H. Toxicology of silica nanoparticles: An update. Arch. Toxicol. 2017, 91, 2967-3010. [CrossRef]

11. Yoshida, T.; Yoshioka, Y.; Fujimura, M.; Yamashita, K.; Higashisaka, K.; Morishita, Y.; Kayamuro, H.; Nabeshi, H.; Nagano, K.; Abe, Y.; et al. Promotion of allergic immune responses by intranasally-administrated nanosilica particles in mice. Nanoscale Res. Lett. 2011, 6, 195. [CrossRef]

12. Dukhin, A.; Goetz, P. Ultrasound for characterizing colloids-particle sizing, zeta potential, rheology. In Studies in Interface Science; Moebius, D., Miller, R., Eds.; Elsevier: Amsterdam, The Netherlands, 2002; 425p.

13. Reeves, P.G.; Nielsen, F.H.; Fahey, G.C.J. AIN-93 purified diets for laboratory rodents: Final report of the American Institute of Nutrition ad hoc writing committee on the reformulation of the AIN-76A rodent diet. J. Nutr. 1993, 123, 1939-1951. [CrossRef] [PubMed]

14. Stuart, C.A.; Twiselton, R.; Nicholas, M.K.; Hide, D.W. Passage of cows' milk protein in breast milk. Clin. Allergy 1984, 14, 533-535. [CrossRef] [PubMed]

15. Johns Hopkins University Animal Care and Use Committee. Available online: http://web.jhu.edu/animalcare/ procedures/rat.html\#normative (accessed on 14 August 2020).

16. Stokes, C.; Miller, B.; Bourne, F. Animal models of food sensitivity. In Food Allergy Isntolerance; Brostoff, J., Challacombe, S., Eds.; W.B. Saunders: Eastbourne, UK, 1987; pp. 286-300.

17. Thomassen, L.C.J.; Aerts, A.; Rabolli, V.; Lison, D.; Gonzalez, L.; Kirsch-Volders, M.; Napierska, D.; Hoet, P.H.; Kirschhock, C.E.A.; Martens, J.A. Synthesis and Characterization of Stable Monodisperse Silica Nanoparticle Sols for in Vitro Cytotoxicity Testing. Langmuir 2010, 26, 328-335. [CrossRef] [PubMed]

18. Nabeshi, H.; Yoshikawa, T.; Matsuyama, K.; Nakazato, Y.; Tochigi, S.; Kondoh, S.; Hirai, T.; Akase, T.; Nagano, K.; Abe, Y.; et al. Amorphous nanosilica induce endocytosis-dependent ROS generation and DNA damage in human keratinocytes. Part. Fibre Toxicol. 2011, 8, 1. [CrossRef]

19. Eom, H.-J.; Choi, J. Oxidative stress of silica nanoparticles in human bronchial epithelial cell, Beas-2B. Toxicol. Vitr. 2009, 23, 1326-1332. [CrossRef]

20. Napierska, D.; Thomassen, L.C.J.; Rabolli, V.; Lison, D.; Gonzalez, L.; Kirsch-Volders, M.; Martens, J.A.; Hoet, P.H. Size-dependent cytotoxicity of monodisperse silica nanoparticles in human endothelial cells. Small 2009, 5, 846-853. [CrossRef]

21. Park, M.V.D.Z.; Annema, W.; Salvati, A.; Lesniak, A.; Elsaesser, A.; Barnes, C.; McKerr, G.; Howard, C.V.; Lynch, I.; Dawson, K.A.; et al. In vitro developmental toxicity test detects inhibition of stem cell differentiation by silica nanoparticles. Toxicol. Appl. Pharmacol. 2009, 240, 108-116. [CrossRef]

22. Ye, Y.; Liu, J.; Xu, J.; Sun, L.; Chen, M.; Lan, M. Nano-SiO 2 induces apoptosis via activation of p53 and Bax mediated by oxidative stress in human hepatic cell line. Toxicol. In Vitro 2010, 24, 751-758. [CrossRef] 
23. Eom, H.-J.; Choi, J. $\mathrm{SiO}_{2}$ Nanoparticles Induced Cytotoxicity by Oxidative Stress in Human Bronchial Epithelial Cell, Beas-2B. Environ. Health Toxicol. 2011, 26, e2011013. [CrossRef]

24. Yang, H.; Wu, Q.; Tang, M.; Liu, X.; Deng, H.; Kong, L.; Lu, Z. In vitro study of silica nanoparticle-induced cytotoxicity based on real-time cell electronic sensing system. J. Nanosci. Nanotechnol. 2010, 10, 561-568. [CrossRef]

25. Yang, X.; Liu, J.; He, H.; Zhou, L.; Gong, C.; Wang, X.; Yang, L.; Yuan, J.; Huang, H.; He, L.; et al. $\mathrm{SiO}_{2}$ nanoparticles induce cytotoxicity and protein expression alteration in HaCaT cells. Part. Fibre Toxicol. 2010, 7, 1. [CrossRef] [PubMed]

26. Duan, J.; Yu, Y.; Li, Y.; Li, Y.; Liu, H.; Jing, L.; Yang, M.; Wang, J.; Li, C.; Sun, Z. Low-dose exposure of silica nanoparticles induces cardiac dysfunction via neutrophil-mediated inflammation and cardiac contraction in zebrafish embryos. Nanotoxicology 2016, 10, 575-585. [CrossRef]

27. Volkheimer, G. Passage of particles through the wall of the gastrointestinal tract. Environ. Health Perspect. 1974, 9, 215-225. [CrossRef]

28. Jani, P.; Halbert, G.W.; Langridge, J.; Florence, A.T. Nanoparticle uptake by the rat gastrointestinal mucosa: Quantitation and particle size dependency. J. Pharm. Pharmacol. 1990, 42, 821-826. [CrossRef]

29. Behrens, I.; Pena, A.I.V.; Alonso, M.J.; Kissel, T. Comparative uptake studies of bioadhesive and non-bioadhesive nanoparticles in human intestinal cell lines and rats: The effect of mucus on particle adsorption and transport. Pharm. Res. 2002, 19, 1185-1193. [CrossRef]

30. Des Rieux, A.; Fievez, V.; Théate, I.; Mast, J.; Préat, V.; Schneider, Y.-J. An improved in vitro model of human intestinal follicle-associated epithelium to study nanoparticle transport by M cells. Eur. J. Pharm. Sci. 2007, 30, 380-391. [CrossRef] [PubMed]

31. De Matteis, V. Exposure to Inorganic Nanoparticles: Routes of Entry, Immune Response, Biodistribution and In Vitro/In Vivo Toxicity Evaluation. Toxics 2017, 5. [CrossRef]

32. Li, L.; Liu, T.; Fu, C.; Tan, L.; Meng, X.; Liu, H. Biodistribution, excretion, and toxicity of mesoporous silica nanoparticles after oral administration depend on their shape. Nanomedicine 2015, 11, 1915-1924. [CrossRef] [PubMed]

33. Pham, D.-H.; Roo, B.D.; Nguyen, X.-B.; Vervaele, M.; Kecskés, A.; Ny, A.; Copmans, D.; Vriens, H.; Locquet, J.-P.; Hoet, P.; et al. Use of zebrafish larvae as a multi-endpoint platform to characterize the toxicity profile of silica nanoparticles. Sci. Rep. 2016, 6, 37145. [CrossRef]

34. Faryadi, S.; Sheikhahmadi, A. Effect of nanosilicon dioxide on growth performance, egg quality, liver histopathology and concentration of calcium, phosphorus and silicon in egg, liver and bone in laying quails. Appl. Nanosci. 2017, 7, 765-772. [CrossRef]

35. Murray, J.; Barbara, J.A.; Dunkley, S.A.; Lopez, A.F.; Van Ostade, X.; Condliffe, A.M.; Dransfield, I.; Haslett, C.; Chilvers, E.R. Regulation of neutrophil apoptosis by tumor necrosis factor-alpha: Requirement for TNFR55 and TNFR75 for induction of apoptosis in vitro. Blood 1997, 90, 2772-2783. [CrossRef]

36. Strieter, R.M.; Kunkel, S.L.; Bone, R.C. Role of tumor necrosis factor-alpha in disease states and inflammation. Crit. Care Med. 1993, 21, S447-63. [CrossRef] [PubMed]

37. Hober, D.; Haque, A.; Wattre, P.; Beaucaire, G.; Mouton, Y.; Capron, A. Production of tumour necrosis factor-alpha (TNF-alpha) and interleukin-1 (IL-1) in patients with AIDS. Enhanced level of TNF-alpha is related to a higher cytotoxic activity. Clin. Exp. Immunol. 1989, 78, 329-333.

38. Kasper, J.; Hermanns, M.I.; Bantz, C.; Maskos, M.; Stauber, R.; Pohl, C.; Unger, R.E.; Kirkpatrick, J.C. Inflammatory and cytotoxic responses of an alveolar-capillary coculture model to silica nanoparticles: Comparison with conventional monocultures. Part. Fibre Toxicol. 2011, 8, 6. [CrossRef]

39. Corbalan, J.J.; Medina, C.; Jacoby, A.; Malinski, T.; Radomski, M.W. Amorphous silica nanoparticles aggregate human platelets: Potential implications for vascular homeostasis. Int. J. Nanomed. 2012, 7, 631-639. [CrossRef] [PubMed]

40. Lin, Y.-S.; Haynes, C.L. Impacts of mesoporous silica nanoparticle size, pore ordering, and pore integrity on hemolytic activity. J. Am. Chem. Soc. 2010, 132, 4834-4842. [CrossRef] [PubMed]

41. Hu, H.; Li, Q.; Jiang, L.; Zou, Y.; Duan, J.; Sun, Z. Genome-wide transcriptional analysis of silica nanoparticles-induced toxicity in zebrafish embryos. Toxicol. Res. 2016, 5, 609-620. [CrossRef] [PubMed]

42. Park, E.-J.; Park, K. Oxidative stress and pro-inflammatory responses induced by silica nanoparticles in vivo and in vitro. Toxicol. Lett. 2009, 184, 18-25. [CrossRef] 
43. Han, B.; Guo, J.; Abrahaley, T.; Qin, L.; Wang, L.; Zheng, Y.; Li, B.; Liu, D.; Yao, H.; Yang, J.; et al. Adverse effect of nano-silicon dioxide on lung function of rats with or without ovalbumin immunization. PLoS ONE 2011, 6, e17236. [CrossRef]

44. Simberg, D.; Zhang, W.-M.; Merkulov, S.; McCrae, K.; Park, J.-H.; Sailor, M.J.; Ruoslahti, E. Contact activation of kallikrein-kinin system by superparamagnetic iron oxide nanoparticles in vitro and in vivo. J. Control. Release 2009, 140, 301-305. [CrossRef]

45. Chen, E.Y.; Garnica, M.; Wang, Y.-C.; Mintz, A.J.; Chen, C.-S.; Chin, W.-C. A mixture of anatase and rutile TiO 2 nanoparticles induces histamine secretion in mast cells. Part. Fibre Toxicol. 2012, 9, 2. [CrossRef] [PubMed]

46. Zaitseva, N.V.; Zemlyanova, M.A.; Zvezdin, V.N.; Dovbysh, A.A.; Gmoshinskiy, I.V.; Khotimchenko, S.A. Impact of silica dioxide nanoparticles on the morphology of internal organs in rats by oral supplementation. Health Risk Anal. 2016, 4, 80-94. [CrossRef]

47. Neurath, M.F. Targeting immune cell circuits and trafficking in inflammatory bowel disease. Nat. Immunol. 2019, 20, 970-979. [CrossRef] [PubMed]

Publisher's Note: MDPI stays neutral with regard to jurisdictional claims in published maps and institutional affiliations.

(C) 2020 by the authors. Licensee MDPI, Basel, Switzerland. This article is an open access article distributed under the terms and conditions of the Creative Commons Attribution (CC BY) license (http://creativecommons.org/licenses/by/4.0/). 